\title{
PENGOLAHAN WADI IKAN PATIN (Pangasius hypophthalmus) PROSES CEPAT DAN TIDAK ASIN
}

\author{
(Processing Catfish Wadi (Pangasius hypophthalmus) Fast And Not Salty Process)
}

\author{
Restu Y. Bakrie \\ Fakultas Perikanan Universitas Kristen Palangka Raya \\ Penulis Koresponden : restului@gmail.com
}

Article Submitted: 20-06-2021

Article Accepted: 15-08-2021

\begin{abstract}
This study aims to determine processing of wadi patin fish (Pangasiu hypophthalmus) quick process and not salty, It is a fermented product from fish, in the form of a wet materi through a salting process, the addition of spices then followed by fermentation for several days until it produces a aroma and taste. This traditional food is the result of fermentation assisted by synergistic microorganisms, namely lactic acid bacteria. The results of the study by washing fish after the salting process were able to accelerate fermentation from 7 days to 3 days. The best treatment to wash the fish meat twice after the salting process. the specifications of the resulting wadi are as follows: protein content $=18.64 \%$; salt content $=0.79 \%$; Water content $=58.65 \%$; Fat content $=3.29 \%$; total microbes $(\mathrm{LAB}) 6.5 \times 104$; organoleptic value $($ taste $)=7.55$.
\end{abstract}

Keywords: Salting, Washing, fish wadi

\section{PENDAHULUAN}

Pengolahan hasil perikanan bertujuan untuk menciptakan produk dengan sifat yang berbeda dari bentuk segar agar disukai oleh konsumen sehingga dapat meningkatkan pola konsumsi terhadap ikan. Hasil olahan tradisional banyak dilakukan dari pada cara moderen, karena prosesnya mudah dan lebih disukai (Anonim, 2001).

Wadi adalah produk olahan berasal dari ternak maupun ikan melaui fermentasi selama beberapa hari sampai mengelurkan aroma khas asam. Dalam pengolahan wadi penggaram merupakan hal yang paling menetukan. Menurut Ahillah, et al., (2017) Penggaraman berfungsi mengawetkan dan mengeluarkan cairan dari jaringan daging untuk substrat pertumbuhan bakteri asam laktat (BAL). Selanjutnya Adawyah (2007). menyatakan bahwa lebih dari satu jenis mikroorganisme yang bersinergi membantu fermentasi.
Ingratubun et al, (2013). Menyatakan mikroorganisme berperan aktif dalam proses fermentasi adalah bakteri asam laktat.

Spesies ikan yang umum diolah menjadi wadi yaitu mengandung cukup lemak, seperti: patin, jelawat, tumbro, tapah, gurami, betok, golongan ikan gabus, nila, sepat rawa, sepat siam (T. pectoralis).

Di Kalimantan Selatan, pengolahan wadi ikan dilakukan dengan cara mencampur ikan yang telah disiangi dan dicuci bersih dengan garam $25-50 \%$ dari berat ikan kemudian dimasukan kedalam wadah kedap udara untuk proses fermentasi selama minimal 14 hari, sehingga rasa sangat asin dan proses fermentasinya terlalu lama, apabila sebelum proses fermentasi ditambah samu dinamakan pakasam. Rita Khairina (1999) menyatakan bahwa konsentrasi garam $(\mathrm{NaCl}) 25 \%$ dengan lama fermentasi 14 hari merupakan produk terbaik wadi ikan betok. Selanjutnya Petrus 
(2013), melaporkan pembuatan wadi ikan papuyu menggunakan garam $15 \%$, gula merah $15 \%$ dan lemon $4 \%$ didapat wadi dengan kategori suka.

Di Kalimantan tengah wadi diolah dengan mencampur garam $10-25 \%$ dari berat ikan bersih, setelah 1 hari dilanjutkan dengan penambahan samu dari beras yang disangrai. Untuk pembuatan samu digunakan beras dolok atau bengawan (Restu, 1999). Pengolahan wadi dengan mencapur garam 10\%; samu beras 5\%; lama fermentasi 7 hari menghasilkan produk sangat asin dan kurang suka (Restu, 2011). Setelah daging ikan toman digarami selama 1 hari, kemudian dicuci, dilanjukatkan fermentasi 7 hari mampu mengurangi rasa asin dan cita-rasa gurih (Restu, 2013). Penambahan gula aren $3 \%$ setelah pencucian daging ikan mas yg digarami mempercepat fermentasi menjadi 3 hari (Restu, 2017).

Khairina (1999), melaporkan mikroflora yang berperan dalam fermentasi adalah bakteri asam laktat dan halofilik dengan menghidrolisis lemak menjadi asam lemak dan gliserol. Aktivitas bakteri saat fermentasi menhasilkan aroma khas dan rasa asam (Reddy, et al., 2008; Masood, et al., 2011). Kemampuan bakteri ini menghidrolisis lemak menjadi asam laktat dengan indeks 1.94 dan 3.96 untuk zona bening. Sesuai dengan pendapat Duhan et al., (2013). peranan penting bakteri asam laktat saat fermentasi adalah mempengaruhi tingkat kesukaan dan masa simpan makanan.

Tujuan Percobaan untuk mempelajari proses pengolahan wadi yang optimal untukdiaplikasikan oleh masyarakat.
Pelaksanaan penelitian mulai 15 Agustus s/d 3 September 2020. Di Laboratorium Fikan Unkrip dan Balai Pengujian Sertifikasi Barang Diperindag. Prov. Kalteng.

\section{METODE PENELITIAN}

Bahan: ikan patin; garam bata; beras; gula merah dan air besih. Alat: pisau; telanan; blender; beskom; dan stoples.

Metode penelitian eksperimen dengan Rancangan Acak Lengkap (Sastrosoepadi, 1999). Perlakuan terhadap daging ikan sebagai berikut:

$$
\begin{aligned}
& \mathrm{A}=\text { Tanpa dicuci } \\
& \mathrm{B}=\text { dicuci } 1 \text { kali } \\
& \mathrm{C}=\text { dicuci } 2 \text { kali }
\end{aligned}
$$

Untuk mengetahui Kualitas wadi setelah proses fermentasi 3 hari, dilakukan uji kimia meliputi kadar air, garam, protein dan lemak); mikrobiologi (TPC) dan uji orgnoleptik terhadap produk wadi, untuk mengambil kesimpulan.

Tahap penelitian:

1. Penyiangan.

2. Daging ikan digarami perbandingan 10:1 dimasukan kedalam stoples dibiarkan selama 1 hari

3. Cuci, tiriskandan tambah gula aren sebanyak 3\%,

4. Tambahkan samu sebanyak $4 \%$ dan dicampur sampai merata.

5. Selanjutnya susun dalam stoples dan ditutup rapat

6. Pproses fermentasi 3 hari

7. Pengambilan contoh uji.

\section{HASIL DAN PEMBAHASAN}

Hasil pengujian laboratorium proksimat daging patin pada tabel 1 berikut:

Tabel 1. Hasil uji prosimat daging patin (\%)

\begin{tabular}{ccccc}
\hline Perlakuan & Air & Protein & Lemak & Garam \\
\hline Patin segar & 74,86 & 18,06 & 4,21 & 0 \\
A & 68,56 & 20,33 & 3,72 & 1,63 \\
B & 68,61 & 20,26 & 3,52 & 1,07 \\
C & 68,58 & 20,12 & 3,48 & 0,91 \\
\hline
\end{tabular}


Hasil analisis kimia wadi patin masingmasing perlakuan setelah proses fermentasi
3 hari (\%), ditampilkan pada gambar 1.

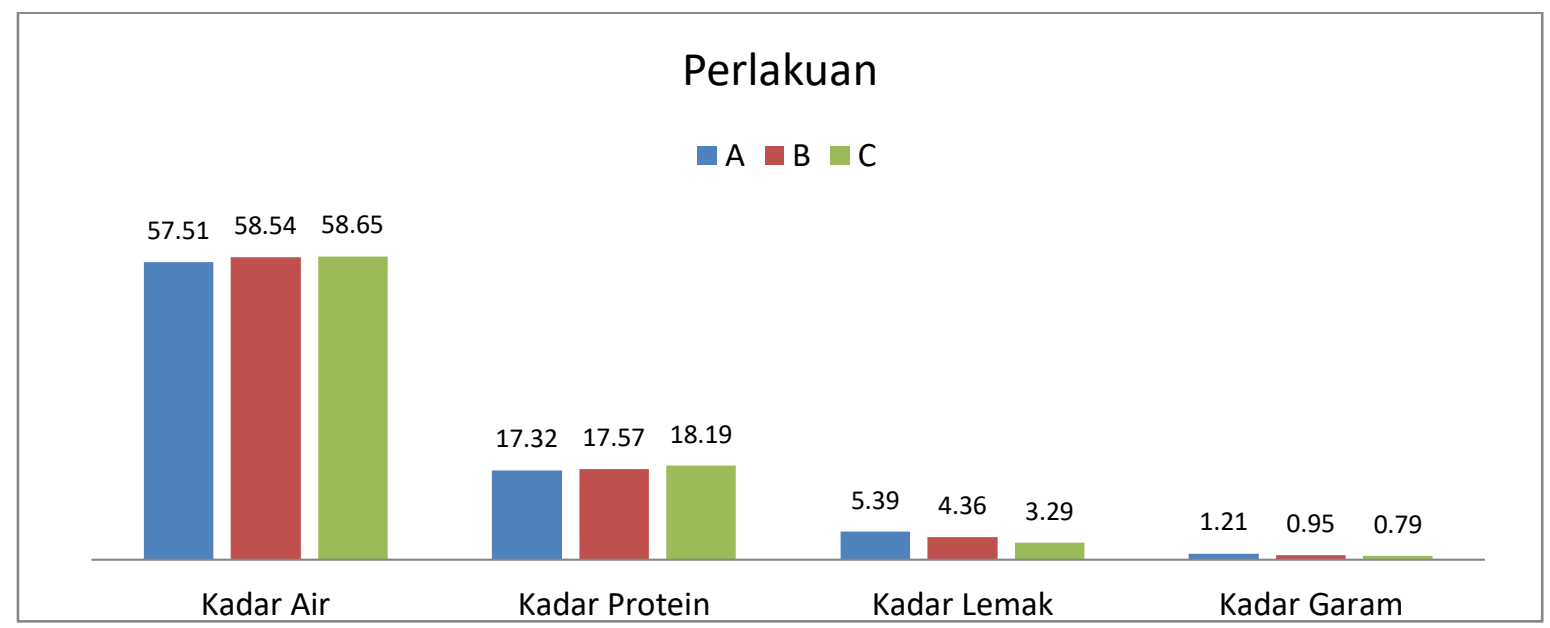

Gambar 1. Hasil Laboratorium prosimat wadi ikan patin (Pangasius sp) setiap perlakuan.

\section{Kadar Air}

Hasil pengujian terhadap kadar air (b/b\%) setelah fermentasi adalah semakin sering pencucian maka kadar air yang dikandung wadi patin bertambah besar.

Pada gambar 1. Dapat dilihat bahwa semakin sering dicuci maka air dalam wadi semakin banyak, disebabkan sifat garam yang dapat menarik air dari jaringan daging ikan telah berkurang akibat pencucian yang dilakukan. Kadar air tertinggi pada C $(58,65)$ kadar air ini lebih banyak dari kadar air wadi ikan betok sebesar $33,29 \%$ setelah masa fermentasi 7 hari dengan konsentrasi garam 10\% (Petrus., et al, 2013). Namun lebih sedikit dari wadi ikan Mas sebanyak $61,11 \%$; wadi bawal $58,74 \%$ ) dan wadi ikan bawal sebanyak 58,74\% (Restu, 2017 dan 2018). Menurut Wati, et al. (2018), semakin banyak konsentrasi garam maka kadar air wadi ikan patin sedikit. Konsentrasi garam $10 \%$ masa fermentasi 6 hari kadar airnya $57,23 \%$.

Hasil analisis keragaman (ANOVA) menyatakan bahwa $\mathrm{F}$ hitung > F tab 1\%, berarti pencucian setelah penggaraman berbeda sangat nyata terhadap kadar air wadi patin. Uji beda nyata terkecil $(\mathrm{BNT})=0,43$ maka ditetapkan Perlakuan A $(57,51)$ beda sangat nyata dengan $\mathrm{B}(58,54)$ dan $\mathrm{C}$ $(58,65)$, sedangkan $\mathrm{B}$ dengan $\mathrm{C}$ tidak berbeda. Hasil ini menunjukan pencucian menyebabkan berkurangnya kadar garam, sehingga mengakibatkan berkurangnya kemampuan kristal garam menarik air dari dalam jaringan daging ikan selama masa fermentasi.

\section{Protein}

Semakin sering daging ikan dicuci setelah penggaraman maka proteinnya rendah. Hal ini terjadi karena dalam proses fermentasi terjadi denaturasi protein oleh bakteri.

Berdasarkan ANOVA kandungan protein wadi patin berbeda sangat nyata. Uji BNT $1 \%=0,32: \mathrm{A}(17,32)$ tidak berbeda dengan B $(17,57)$, sedangkan $\mathrm{C}(18,19)$ berbeda sangat nyata terhadap A dan B.

Kadar protein tertinggi diperoleh dalam produk $\mathrm{C}=18,19 \%$, lebih rendah dari protein wadi ikan mas $26,8 \%$ (Restu,1999), patin $18,40 \%$ tanpa dicuci setelah masa penggaraman dengan masa fermentasi 7 hari (Restu, 2011). Namun 
lebih besar dari protein wadi betok 12,33\% (Petrus., et al, 2013); protein wadi patin dengan konsentrasi garam $10 \%$ dengan masa fermentasi 6 hari 16,09\% (Wati., et al. (2018); protein bakasang laor $13,78 \%$ masa fermentasi 10 hari dengan kadar garam $10 \%$ (Mahulete., et al, 2020).

Menurut Adawyah (2007), selama fermentasi protein akan dihidrolisis oleh bakteri menjadi asam amino, kemudian diurai menjadi komponen-komponen yang membentuk citarasa produk. Kadar garam tinggi menyebabkan kelarutan protein rendah, kemudian protein terpisah dan membentuk endapan (Thariq., et al., 2014).

\section{Lemak}

Hasi laboratotium terhadap kadar lemak pada produk wadi ikan patin $\mathrm{A}=$ $5,39 \%, \mathrm{~B}=4,36 \%$ dan $\mathrm{C}=3,29 \%$.

Pada gambar 1 terlihat bahwa rerata kadar lemak yang dikandung oleh setiap perlakuan semakin menurun seiring dengan seringnya daging ikan dicuci dan proses fermentasi. Kadar lemak wadi patin ini lebih besar dari wadi ikan mas 3,01\% masa fermentasi 7 hari (Restu, 1999); lemak wadi patin 2,29\% perlakuan tanpa dicuci dan penambahan samu 5\% (Restu, 2011). Demikian juga lemak wadi ikan toman perlakuan tidak dicuci setelah penggaram A $(2,62 \%)$; dicuci satu kali B $(2,29 \%)$ dan dua kali C(2,02\%) (Restu, 2013); kadar lemak wadi ikan betok $=2,15 \%$ (Petrus, et al., 2013); lemak wadi bawak air tawar (Colossoms macropomum) sebesar 0,60 0,73\% (Restu, 2018).

Hasil Anova menunjukan bahwa $\mathrm{F}$ hitung > $\mathrm{F}$ tab $1 \%$. Hal ini menyatakan kandungan lemak wadi patin berbeda sangat nyata pada setiap perlakuan. Perhitungan BNT (1\%) diperoleh nilai pembeda 0,31 . Dengan demikian dinyatakan semua perlakuan berbeda sangat nyata kandungan kadar lemaknya. Hal ini disebabkan karena proses pencucian setelah penggaraman dan lama fermentasi 3 hari dapat mengurangi kadar lemak dari dari daging ikan.

\section{Garam}

Setelah proses fermentasi persentase kadar garam wadi patin semakin rendah. Perlakuan A $(1,21)$; B $(0,95)$; dan C $(0,79)$. Hal ini terjadi karena selama proses fermentasi, air bersama garam terus keluar dari daging ikan. Anova terhadap kandungan garam membuktikan setiap perlakuan berbeda yang sangat nyata.

Hasil uji BNT diperoleh nilai 0,19, sehingga kadar garam wadi ini lebih rendah dari wadi ikan mas 2,82\% (Restu,1999); wadi betok $3,26 \%$ dengan konsentrasi garam $10 \%$ setelah masa fermentasi 7 hari (Petrus, et al., 2013), kadar garam ikan kering asin kambing-kambing sebesar 8,02\% setelah lama penggaraman 24 jam dengan kosentrasi garam 10\% (Abadiansyah., et al., 2018). Penurunan kandungan garam disebabkan karena proses pencucian daging ikan setelah penggaraman dan fermentasi 3 hari, sehingga garam keluar dari dalam daging ikan berupa cairan.

\section{Mikrobia}

Hasil hitungan koloni bakteri di Laboratorium ditampilkan gambar 2 . Berdasarkan anasisis statistik diperoeh $(\mathrm{p} \geq$ $0,05 \leq 0,01)$, berarti perlakuan yang diberikan mempunyai pengaruh pada jumlah koloni bakteri didalam wadi. Rata-rata perlakuan A $(4,7)$ berbeda nyata dengan B $(6,3)$ dan $\mathrm{C}(6,7)$, tetapi B tidak berbeda dengan C. Semakin rendah kadar garam maka semakin banyak jumlah koloni bakteri, ini disebabkan garam dapat menghambat pertumbuhan mikroba.

Total mikrobia (CPU/gr) perlakuan A $\left(4,7 \times 10^{4}\right) ; \quad \mathrm{B}\left(6,3 \times 10^{4}\right) ; \quad \mathrm{C}\left(6,7 \times 10^{4}\right)$. Total mikroba wadi patin ini lebih rendah dari mikroba hasil fermentasi ngari (makanan tradisional di India) sebanyak $10^{4}-10^{6}$ CPU/gr (Taorem dan Sarojnalini, 2012); pada fermentasi usus ikan cakalang segar (Katsuwonis sp. L) diperoleh mikroba sebanyak $1,8 \times 10^{6} \mathrm{CPU} / \mathrm{gr}$ (Ingratubun, et al., 2013); jumlah mikroba hasil Fermentasi ikan wader (Rasbora) kadar garam 25\%

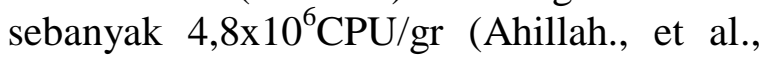


2017). Melalui proses fermentasi karbohidrat diubah oleh bakteri menggunakan enzim amilase ekstraseluler secara anaerob sehingga mengasilkan asam laktat (Reddy et al., 2008); selanjutnya Widyastuti (2016), mengemukakan bahwa bakteri ini berkembang dengan baik pada media yang cukup gula.

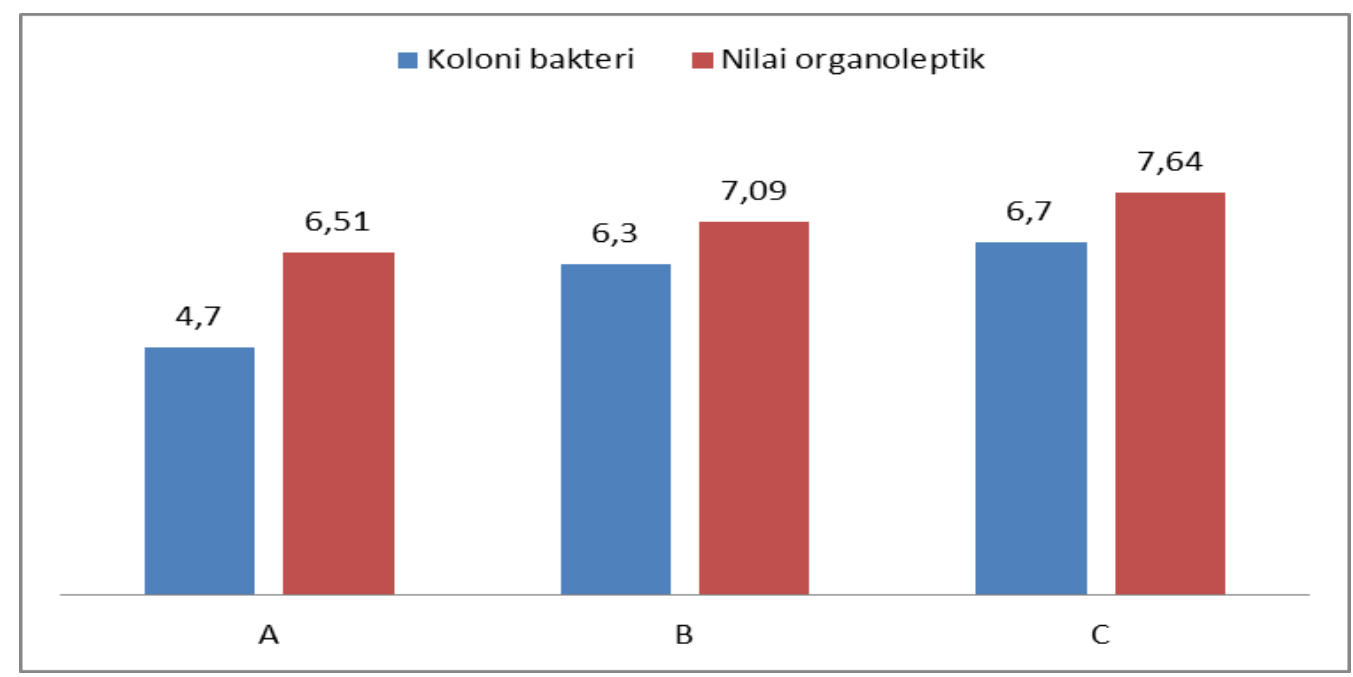

Gambar 2. Hasil Laboratorium koloni bakteri dan Nilai uji organoleptik wadi ikan patin setiap perlakuan.

\section{Uji Organoleptik}

Uji untuk mengetahui tingkat kesukaan dilakukan oleh 5 orang panelis terhadap wadi patin berdasarkan indikator: penampilan, tekstur, aroma dan rasa. Hasil uji dalam gambar 2, menunjukan nilai tertinggi pada $C(7,63)$. Nilai ini lebih tinggi dari standar ikan pindang mutu I yaitu 7,5 (Sudarisman dan Elvina,1996); Nilai 7,60 untuk wadi ikan patin tanpa gula aren (Restu, 2012). Gula aren 15\% dalam fermentasi wadi ikan betok mampu meningkatkan kesukaan panelis (Petrus, 2013). Selanjutnya Restu (2017; 2018; 2019), penambahan gula aren $3 \%$ untuk wadi ikan mas nilai suka adalah 7,60 ; wadi ikan bawal air tawa 7,61, dan nilai 7,2 wadi patin dikemas dengan kantong plastik kemudian disimpan selam 15 hari di dalam ember penuh air.

Menurut Efendi (2010), protein dan lemak terdegradasi oleh bakteri menghasilkan rasa dan aroma khas karena senyawa methil keton, aldehid, asam amino.
Catatan khusus hasil penelitian ini bahwa aroma wadi ikan patin goreng sangat menarik selera.

\section{KESIMPULAN DAN SARAN}

Dalam proses pengolahan wadi, daging ikan yang telah digarami selama satu hari harus dicuci terlebih dahulu sebelum penambahan gula aren dan samu, sehingga dapat memperpendek waktu fementasi dari 7 menjadi 3 hari. Kualitas wadi terbaik adalah perlakuan pencucian daging ikan dua kali. Spesifikasi wadi: kadar air $(58,65 \%)$; protein $(18,19 \%)$; lemak $\quad(3,29 \%)$; abu $(5,46 \%)$; garam $(0,79 \%)$; total mikrobia (BAL) $6,7 \times 10^{4}$; nilai organoleptik 7,64 .

Disarankan sebelum penambahan gula aren dan samu, daging ikan yang telah digarami dicuci terlebih dahulu dengan air bersih, sehingga diperoleh wadi ikan yang disukai. 


\section{DAFTAR PUSTAKA}

Adawyah, 2007. Pengolahan dan Pengawetan Ikan. Bumi Aksara, Jakarta

Anonim, 2001. Hasil Uji Coba Pengolahan Hasil Perikanan pada LPPMHP. Dinas Kelautan Dan perikanan Propinsi Kalimantan Tengah, Palangkaraya.

Afrianto E., dan Liviawati E., (1989). Pengawetan dan Pengolahan Ikan. Penerbit Kanisius. Yogyakarta.

Ahilah N, Aoda R, Windi, Reni S, Rita P., 2017. Pengaruh Konsentrasi Garam Pada Fermentasi Ikan Wader (Rasbora lateristriata). Jurnal Bioedukasi. 10(2): 12-17

Akbardiansyah, Desniar, Uju, 2018. Karakteristik Ikan Asin Kambingkambing (Chanthidermis maculata) Penggaraman Kering. Jurnal Pengolahan Hasil Perikanan Indonesia. 10(2):345-355.

Duhan, J.S., Nehra, K., Gahlawat, S.K., Saharan, P., and Surkha D., (2013)Bacteriocins From Latic Acid Bacteria. Biotechnology: Prospects and Applications Springer. 1(10), 127141.

Efendy, Y dan Yusra, 2010. Dasar-Dasar Teknologi Hasil Perikanan. Univ. Bung Hatta Press, Padang.

Ingratubun, J.A., Ijong,F.g., Onibala,H. 2013. Isolasi dan Indentifikasi Bakteri Asam Laktat pada Produk Fermentasi. Aquatic Science and Management Journal. 1, 48-56

Masood, M., et all., 2011. Beneficial Effects of Lactic Acid Bacteria on Human beings. Critical Reviews in Microbiology, 37(1): 91-98.

Mahulette F, Steven E, Calvin T, Frengki W., 2020. Pengaruh kadar Garam Dan Lama Fermentasi Terhadap Kualitas Bakasang Laor. Jurnal Teknologi Pangan. 14(1): 40-51

Mirza Yanuar, Rizka DF, Utami SH, Sitoresmi P., 2017. Identifikasi Kemampuan Hidrolisis Lemak Dan Penentuan Indeks Zona Bening Asam Laktat Pada Bakteri Dalam Wadi Makanan Traditional Kalimantan Tengah. Jurnal Bionature. 18(2):8798.

Petrus, Hari Purnomo, Eddy S., Handoko, 2013. Physicochemical characteristics, sensory acceptability and microbial quality Wadi Betok a traditional fermented fish from south Kalimantan. International Food Research Journal 20(2): 933- 939

Petrus S, 2013. Quality of fermented Betok fish added with palm (Arenga $s p$ ) sugar and Lime juice. International Food Research Journal 20(5): 2849 2855

Restu, Saptono dan Yuanike, 1999. Pengaruh Jenis Beras Terhadap Citarasa Wadi Ikan Mas. Laporan Penelitian, Fak. Perikanan UNKRIP.

Restu, 2011. Pengaruh Persentase Samu Dalam Pembuatan Wadi Patin (Pangasius sp). Journal Of Tropical Fisheries. 6(1): 553-557.

Restu, 2013. Pengaruh Pencucian Daging Ikan Toman (Channa sp) Setelah digarami Terhadap Cita-rasa Wadi. Jurnal Ilmu Hewani Tropika. 2(1): 3134. 
Restu, 2015. Percobaan Penurunan Kadar Air Wadi Ikan Patin $(P$. hypophthalamus) untuk daya awet. Jurnal Ilmu Hewani Tropika. 4(1): 1215 .

Restu, 2017. Pengaruh Persentase dan Kombinasi Gula Aren dengan Samu dalam Fermentasi ikan mas (Cyprinus carpio). Jurnal Ilmu Hewani Tropika. 6(2): $78-81$

Restu, 2018. Pengolahan Wadi ikan bawal air tawar (Colossoma macropomum). Jurnal Ilmu Hewani Tropika. 7(2): 7073.

Restu, 2019. Nilai Organoleptik Wadi Ikan Patin (Pangasius sp) selama penyimpanan di dalam air. Jurnal Ilmu Hewani Tropika. 8(2): 98-103.

Rita Khairina, Tyas Utami dan Erni Hemayani, 1999. Perubahan Sifat Kimia, Fisik, Mikrobia dan Sensoris Produk Wadi Ikan Betok (Anabas testudineus Bloch). Jurnal Agritech 19(4):181-188
Sastrosupadi, 1999. Rancangan Percobaan Praktis. Penerbit Kanisius, Jogyakarta.

Sudarisman dan Elvina, 1996. Petunjuk Memilih Produk Ikan dan Daging. Penebar Swadaya,Jakarta.

Taorem, S., Sarojanlini, C.H., 2012. Effect of Temperature on Biochemical of Ngari. Nature and Science journal 10(2): 32-40

Thariq, A.S., Swastawati, F., dan Surti,T., 2014. Pengaruh Perbedan Konsentrasi Garam pada Peda Ikan Kembung (Rastreliger neglectus) terhadap Kandungan asan Glutamat Pemberi rasa Gurih. Jurnal Pengolahan dan Bioteknologi Hasil Perikanan, 3(3):104

Wati Kharina, Ekawati P., Sinung Pranata, 2019. Kualitas Fermentasi Spontan Wadi Ikan Patin (Pangasius sp) Dengan Variasi Konsentrasi Garam. Jurnal Biota. 4(1):24-32 